\title{
Time and Truth in Thucydides ${ }^{1}$
}

\section{Tiempo y verdad en Tucídides}

\author{
Carlo Marcaccini ${ }^{2}$ \\ Independent scholar (Italia)
}

Recibido: 27-02-17

Aprobado: 18-03-17

\begin{abstract}
In the first chapters on the method and in the so called archaiologia, Thucydides uses a vocabulary similar to that of the Hippocratic writers, yet his concept of time is different. While the ancient physicians have a linear conception of time and use the signs and experiences of the past to predict the future, Thucydides has a circular conception of time; that is, he distances the present from the past and interprets the second on the basis of the first. For Thucydides, it is not the past that influences the present, but the present that allows us to build a story of the past. To explain this epistemological difference between Thucydides and the Hippocratic physicians I use the theories of Paul Ricoeur, who, starting from Augustine's reflection on the time, identified the nature of historical narrative as a manifestation of an internal temporal experience, defining the memory as "the present of the past".
\end{abstract}

Key-words: Thucydides, Augustine, Hippocrates, Historical Epistemology, Conception of Time.

\section{Resumen}

En los primeros capítulos acerca del método y de la llamada archaiologia, Tucídides usa un vocabulario similar al de los escritores hipocráticos, si

\footnotetext{
${ }^{1}$ I wish to express my deeper gratitude to Erin Larkin and Filippo Naitana for translating this paper into English. I also thank Alessio Ceccherini, Massimo Menichetti and Antonis Tsakmakis for their useful comments and suggestions.

2 (carlo.marcaccini@gmail.com) Indipendent scholar of ancient Greek history. His main interests are ancient ethnography, archaic Greek civilization, politics of the Classic period. His main works include Costruire un 'identità, scrivere la storia. Archiloco, Paro e la colonizzazione di Taso (Firenze, 2001); Atene sovietica. Democrazia antica e rivoluzione comunista (Pisa, 2012).
} 
bien su concepto del tiempo es diferente.. Mientras los médicos antiguos poseen una concepción lineal del tiempo y usan los signos y experiencias del pasado para predecir el futuro, Tucídides tiene una concepción circular del tiempo; esto es, él distingue el presente del pasado e interpreta el segundo en base al primero. Para Tucídides, no es el pasado el que influye en el presente, sino que es el presente el que nos permite construir una historia del pasado. Para explicar esta distinción epistemológica entre Tucídides y los médicos hipocráticos recurro a las teorías de Paul Ricoeur, quien, empezando por la reflexión de Agustín acerca del tiempo, identificó la naturaleza de la narrativa histórica como manifestación de una experiencia temporal interna, definiendo la memoria como "el presente del pasado".

Palabras-clave: Tucídides, Agustín, Hipócrates, epistemología histórica, concepción del tiempo.

In the first chapters of his opus Thucydides attaches great importance to the sensible reconstruction of the past and raises the larger problem of the nature of history (1.1-22) ${ }^{3}$. The type of evidence on which historical investigation relies does not present itself in the form of verifiable and replicable experiment, but implies on the one hand the "deconstruction" of a false conscience (for example, the false tradition on the tyrannicides in 1.20.1-2; 6.54-59), and on the other a critical examination of the data available. In this respect, Thucydides' historiography shows a connection with medical epistemology; that is, it gives crucial importance to signs, proof, "traces" in the quest for truth. In order to clarify the ways in which such connection is forged, I will explore a number of methodological questions in some of the treaties that comprise the Corpus hippocraticum ${ }^{4}$, with special focus on the concept of time. In particular, I will show how Thucydides, although influenced by Hippocrates' empiricism, takes "an epistemological leap" with respect to medical knowledge in articulating the connection between past and present.

To best appreciate this point, I believe it is first necessary to introduce a theoretical premise on the relationship between time and narrative, starting with the treatise contained in the eleventh book of Augustine's Confessions, according

\footnotetext{
${ }^{3}$ On the beginning chapters and methodology of Thucydides, see Canfora 1972: 57-86; Connor 1984: 20-32; Loraux 1986; Hornblower 1987: 73-109; Darbo-Peschanski 1989; Tsakmakis 1995: 18 63; Moles 2001; Rood 2006; Forsdyke 2017.

${ }^{4}$ The bibliography on Hippocrates is extensive. I will limit myself to mentioning only a few texts: Vegetti 1965: 10-77; Grmek 1980; Lasserre, Mudry 1983; Di Benedetto 1986; Jouanna 1994; Jouanna 2009; Jouanna 2013: 85-86 for a literature review. In the past the positivist historians laid emphasis on the relationship between medicine and historiography; recently, there has been a reassertion of Thucydides' originality, not only with respect to medicine, but also sophistry and legal oratory. See, for example: Stahl 2003: 13-35; cfr. Thomas 2006; Ead. 2017; Foster, Lateiner 2012: 1-9.
} 
to Paul Ricoeur's reading of it in the first volume of Temps et récit ${ }^{5}$. Using the Augustinian text as a point of departure, Ricoeur establishes the present, the past and the future in a dialectic relationship of an essentially circular nature, as part of one singular spiritual process; in this way, he makes the interior experience of time lived coincide with time narrated ${ }^{6}$. Next I will examine some treatises of the Corpus hippocraticum, in which the tria tempora are the moments placed in sequence one after the other in consequential and tendential order. Finally, I will demonstrate how Thucydides, in separating the past and the present, consciously distances himself from medical knowledge and adopts a conception of time analogous to that exemplified by Ricoeur (through Augustine), in order to confer a kind of completeness of meaning to his narration ${ }^{7}$.

I will start by saying that this examination of the Confessions has an ontological nature, and moreover is framed within a broader theological question, that of the eternity of $\operatorname{God}^{8}$. Eternity contributes to the definition of time, though in negative terms, through the idea of limit ${ }^{9}$. Time is circumscribed; it has a beginning and an end, and for this reason it is also transitory, not continuing for all eternity. These characteristics emerge in opposition to the infinite, immobile and -indeed- eternal nature of God. It is certainly a paradox that it is the ontological ineffability of time -its "not-being" placed before the divine "being"- that allows us to conceive and define it; but it is precisely within this framework that Augustine slowly evolves in his pursuit of the truth, and touches on the question of the historical narrative too. Time, in fact, for however great its reach, shares with narrative the quality of being defined by clear boundaries; therefore, the cosmic opposition characterized by Augustine between human time and divine non-time explains the limit in which every narrative time exists.

The starting point in Augustine is the quantification of time: he affirms the impossibility of grasping both its existence and measurability, as it is lacking dimension or extension. The past and the future, in fact, do not exist, because the first is no longer and the second is not yet, while the present does not persist and therefore cannot be grasped in a broad sense (11.14-16). Augustine acknowledges the existence of the tria tempora, yet he does not situate them in a physical dimension, but in the human mind. Those who narrate past events

\footnotetext{
5 August., Conf. 11.13-31. Ricouer 1983: 19-53.

${ }^{6}$ For a different point of view on the hermeneutics of temporality in relationship to Greek historiography see Darbo-Peschanski 2000a: 11-21; Ead. 2000b: 89-91, 110-114.

${ }^{7}$ Ricoeur surpasses both the nomology of Anglosaxon analytic philosophy (useful to focus on the concept of cause: Ricoeur 1983: 159-202; Ricoeur 2010) and the narratological readings (which are however a necessary step to go beyond the structuralism and the "nouvelle histoire": Ricoeur 1983: 228-246). For a narratological approach to the Thucydidean text, see Rood 1998; Id. 2007; and works in Tsakmakis, Tamiolaki 2013; see also Hornblower 1994; Stahl 2006: 328-334. On the epistemology of historical knowledge, see finally the seminal Veyne 1973; De Certeau 1977; Koselleck 1986. A good literary review covering the last century can be found in Aurell 2011.

${ }^{8}$ August., Conf. 11.13.29-31.

9 Ricoeur 1983: 41-53.
} 
would not recount true things if they did not see them in their mind (si animo illa non cernerent, 11.17.9-10). Augustine explains that when things that have actually happened are recounted, from memory come words formed by their imagination (verba concepta ex imaginibus earum), which like imprints (vestigia) fasten themselves on the mind through the senses (11.18.7-10). There is a close relationship between seeing (videre, cernere) and narrating, a nexus that flows from the traces left in memory and that gives access to the knowledge of the past. For example, Augustine's childhood is in the past and no longer exists, yet he is able to see images from it the moment in which he recalls and speaks of it (imaginem vero eius, cum eam recolo et narro, in praesenti tempore intueor, 11.18.11-13). The past lives in a figurative sense in the story, thanks to traces, the signs that are left in the present. Thus, the story not only is the only way to represent time passed, as a living metaphor for that which no longer exists, but is tantamount to the process of knowing the past as it renders its signs visible, the imprints left on the mind. The same happens with the future. Augustine maintains that it cannot be seen either, since it does not yet exist, but we can glimpse its causae and signa in the present and predict what will happen. One example is the dawn that comes before sunrise. To see the dawn allows me to see the birth of the sun; that is, to imagine it and thus to foresee it. Neither the sight of the dawn, nor the imagination of sunrise coincides with the sunrise itself, but their intuition in the present allows us to foretell what is about to happen (11.18.13-40).

The imagination of the past and the future, which is a conjecture of what has been or will be, has no other place or support if not our mind, which in the present can extend ahead or backwards in time. Augustine distinguishes between "the present of the past", "the present of the present" and "the present of the future": the first consists in memoria, the second in contuitus (that is, intuition), the third in the expectatio (that is, the waiting) (11.20). The action of foreseeing, remembering or expecting something happens in the present and within the mind, which moves between past and future. Augustine introduces thus the concept of the extension of the mind (distentio animi), but since it has a spatial connotation that implicates the idea of movement he must specify how the movement of time must be understood ${ }^{10}$. He asks himself: sed unde et qua et quo praeterit (tempus), cum metitur? (11.21.10-11). The answer is that time comes from the future, passes through the present and joins the past. But in what way can that happen? How can we conceive this transition since the future and the past do not exist while the present is an ineffable instant? Augustine cites the well known examples of sound and song. He writes that when one wishes to recite a poem or a speech (11.27.56-57), one rehearses to oneself its length, goes over its duration in time in silence and, once it is committed to memory, begins to recite the sounds to the predetermined conclusion: in this way, the present intention shifts the future into the past, diminishing the future and growing the past until the future is exhausted

\footnotetext{
${ }^{10}$ See Ricoeur 1983: 34-41 and Id. 2004: 23-33.
} 
and everything becomes past (prasens intentio futurum in praeteritum traicit deminutione futuri crescente praeterito, donec consumptione futuri sit totum praeteritum, 11.27.65-67).

Having explained that the movement of time corresponds to the expansion of the mind, Augustine returns to qualifying the tria tempora according to their corresponding mental affections. The mind has expectations, pays attention and remembers, in such a way that what is waited for (the future) through that which has our attention (present) passes into the memory (the past) (nam et exspectat et adtendit et meminit, ut id quod expectat per id quod adtendit transeat in id quod meminerit, 11.28.3-5). The point made up of the intentio or adtentio animi, is the present through which what comes from the future tends to retreat into the past (sed tamen perdurat attentio, per quam pergat abesse quod aderit, 11.28.910). Thanks to this precise action the expansion of time can occur; that is, the continuous transmission of expectation to memory. According to Augustine, this is what happens in song, in the life of a man and also in the happening of generations: a conclusion that transforms the fragile example of the canticus into an efficient paradigm in which, according to Ricoeur, "tout l'empire du narratif est ici virtuellement déployé: depuis le simple poème, en passant par l'histoire d'une vie entière, jusqu'à l'histoire universelle"ll.

From this conclusion that rises onto a cosmic plane, one understands how temporal spatiality, which implicates the idea of movement from the future to the past, is resolved in conceptual terms and localized within the mind. It clearly follows that the dialectic of the tria tempora, according to which the future becomes the past in a continuous process, is rendered possible by the intellectual activity that Augustine calls intentio animi, which Ricoeur defines "historical intentionality": on the theoretical plane it is the awareness of attributing meaning to events, while on a practical level it is nothing more than the capacity of the historian to put facts in order creating a coherent storyline ${ }^{12}$. This intellectual act happens in the present and encompasses in just one entity three different points in time, or else it allows the mind to expand forward and backwards in time, giving space to that which is commonly called its "flowing" (distentio animi). Augustine speaks of the present of the present, the present of the past and the present of the future: the vision of what has happened before and what will happen after takes place within the conscience that remembers or foretells. Ricoeur explains that “c'est dans l'âme, donc à titre d'impression, que l'attente et la mémoire ont de l'extension. Mais l'impression n'est dans l'âme que pour autant que l'esprit agit, c'est-à-dire attend, fait attention et se souvient"'13. We have seen what happens in three steps: first there are the signs, the traces (signa, vestigia) of the past -or of the future- that are imprinted upon the mind; then, on the basis of these, the mind conjures images, i.e. conjectures; from these come finally the words of the

${ }^{11}$ Ricoeur 1983: 41.

${ }^{12}$ Ricoeur 1983: 247-313, 317-319.

${ }_{13}$ Ricoeur 1983: 38. The trace-representation-memory nexus is developed in Ricoeur 2000: 5-66. 
story. Thus, signs, conjectures, words, but the act is instantaneous and occurs in the present.

As has already been said, the Augustinian inquiry is of the ontological sort, but in accounting for the stages of knowledge of the past and the future, it assumes an epistemological relevance as well. The fundamental idea that Ricoeur takes from it is that narrative is not an accessory of historical consciousness, but constitutes its very nature: vision - that is of a conjectural nature and elicited by the signa and the vestigia - is performed in a narrative structure without which it is not possible to move either forward or backwards in time ${ }^{14}$. Moreover, the narrative incarnates the totality of time, even if in the dialectical articulation of the tria tempora, according to which without the future there is no past, without expectation there is no memory ${ }^{15}$. The mental affections, such as illusion and hope, are also ascribable within a temporal perspective: not coincidentally historical treatises often include psychological descriptions of their protagonists' passions (whether individual or collective), which are not ornamental elements but - precisely since they depend on the narrative sensibility of the author- must be considered as an essential support of the temporal totality described in the account ${ }^{16}$. Passions give the narration intensity and range; for example, an expression that could seem banal if it did not recall the Augustinian opposition between intentio and distentio animi.

Finally, I want to reiterate what I alluded to at the beginning of this article. The concept of limit is crucial to understand the time-narrative equation. Time is defined by a limit (for Augustine the eternity of God) that exists to negate it and, for this same reason, allows us to define it or -as Ricoeur asserts- to intensify it; that is, to draw “de l'expérience même du temps des ressources de hièrarchisation interne dont le bénéficie n'est pas d'abolir la temporalité mais de l'approfondir"17. This means that, in order to go beyond a mere linear conception of time, it is not enough to simply eliminate a narrative's chronology, but one must attempt to understand temporal dialectics. In a song, to return to Augustine's well-known example, or a narrative, finiteness is presented as a characteristic of the story as a circumscribed whole. The action of the intellect -its intention or "historical intentionality"- causes us to go over time in the narrative, placing ourselves forward and consuming it in its entirety, until all of the future has become past. This circular distentio - which occurs before the readers or viewers- reproduces the author's vision of the pursuit as a whole, in which the future precedes the past and gives it meaning: in fact, in the writing of a story it is the end that gives meaning to the beginning. For this reason, the idea-limit -that is, the delimitation of time- has great epistemological consequence.

\footnotetext{
14 Ricoeur 1985: 153-183; Id. 2000: 191-230.

15 In this respect, Ricouer proposes a comparison between the ontology of the historical condition and the epistemology of historical knowledge: Ricoeur 2000: 449-471.

${ }^{16}$ See, for example, Thuc. 3.45.4-6; 5.102-104.

17 Ricoeur 1983: 53.
} 
Let us now move to the lexicon of evidence offered in the treatises of the Corpus hippocraticum. Medical hermeneutics consist in the interpretation of signs that manifest themselves on the exterior of a patient's body in order to identify an illness, reconstruct its causes or predict its development. Going through the Corpus, it is not unusual to find expressions such as "this is the sign of", "this indicates that...", "I consider that this is proof that...", "on the basis of this information we can presuppose that...", "it is plausible that...". The

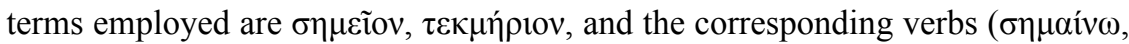

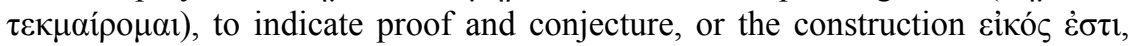
that serves to infer a plausible conclusion ${ }^{18}$. Each of these words can have a different connotation, depending on the context, but they all express a line of thinking that -though based on direct observation- goes beyond the sphere of a perceivable immediacy. The implied inference in the sign allows us to go beyond the dimension of mere phenomenology and perform intellectual inquiry.

This methodology is not original to the medical techne, though it does lay claim to and perfect it; instead, it has a place in the opposition between the visible and the invisible already identified by presocratic philosophers ${ }^{19}$. They postulated two kinds of knowledge: one based on what appears at first sight and for this reason is often revealed fallacious; the other accessible only to the gods but precluded from the human mind, incapable of having clear vision of the truth. For some this dichotomy implicates a deep skepticism of human intellectual capability, the same that we find already in the poets of the archaic period ${ }^{20}$; others instead see in phenomenical reality the possibility of entering deeper truths. Xenophanes affirms that no human will ever know a certain truth ( $\tau$ ò $\sigma \alpha \varphi \varepsilon ́ s$ ) with regard to the gods, and in the case that one does say something true, he or she would not know it with certainty, as it is opinion

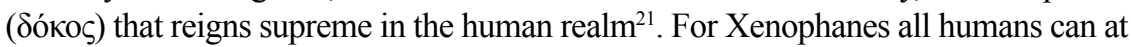
most simulate the truth, try to reproduce it through similitude (غ่oikó $\alpha$ ), as he affirms in another fragment ${ }^{22}$, but the realm of the invisible will be precluded to them. The analogy is a frequent device in archaic Greek science, in particular in cosmological theories, and serves to circumvent empirical proof: for example, in medicine, we often find a political metaphor to illustrate the body's state of health ${ }^{23}$.

${ }_{18}$ Lloyd 1966: 424-429; Di Benedetto 1986: 97-102; Jori 1996: 417-441; Jouanna 1994: 321-326; Fausti 2010. For a general overview on the idea of knowledge in Greek philosopy, see Brunschwig 2007.

${ }^{19}$ Lloyd 1966: 210-303; Hussey 1990; Hussey 1995; Jouanna 1994: 321-326; Jori 1992; Jori 1996: 417-441.

${ }^{20}$ According to Homer, only the gods have total knowledge of the present, the past and the future (Il. 1.70); see Hussey 1990: 11-17.

${ }^{21}$ Xenophanes 21 B34 DK: "As for the certain truth no man has known, nor will any know it, concerning the gods and about all the other things that I am saying. For however much he might chance to say what has actually been brought to pass, still he himself does not know; it is opinion that is constructed in all cases" (transl. Hussey 1990: 18).

22 Xenophanes 21 B35 DK: "Let these then be held as opinion resembling the truth" (transl. Hussey 1990); see Parmenides 28 B8, 60-61.

${ }_{23}$ See Alcmaeon 24 B4 DK; Hippoc., VM 16. 1. Also: Cambiano 1983; Vegetti 1983; Jouanna 1994: 331-335. 
Aglimmer opens with Alcmaeon of Croton, a physician of the Pythagorean school

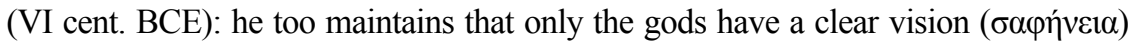
of things that do not appear, but on the other hand, it is the domain of humans to make conjecture ( $\tau \varepsilon \kappa \mu \alpha i ́ p \varepsilon \sigma \theta \alpha \mathrm{l}: 24 \mathrm{~B} 1 \mathrm{DK})$. Conjecture, that is, an intelligence based on interpretation of evidence and signs, goes beyond the mechanism of analogy and breaks the barrier of the invisible, that now can be penetrated by human rationality ${ }^{24}$. There is a saying by Anaxagoras that is proverbial in this regard, according to which the things that are seen ( $\tau \grave{\alpha} \varphi \alpha$ ovó $\mu \varepsilon v \alpha$ ) are the visible part of what is not seen $(\not \partial \psi 1 \varsigma \dot{\alpha} \delta \dot{\eta} \lambda \omega v)^{25}$. Two types of knowledge remain, one connected to the exclusive perception of the senses, the other based on reason: but both are included in the human realm that reabsorbs the whole truth in its conjectural frame and therefore abandons the presumption that there is an unattainable truth, which one can hope to gain only drawing indemonstrable hypotheses ${ }^{26}$.

This is the principle of the Hippocratic treatise On Ancient Medicine asserted by the author. The treatise challenges a method based on abstract postulates (íón $\theta \varepsilon \sigma i \varsigma)$ and affirms the necessity on the part of the doctor to use an empirical method based on experience ${ }^{27}$. The author's polemical target are those who have abandoned the ways of the medical arts in favor of practicing their research in a philosophical way. The example of cosmology, and in general that of physics, serves to clarify the difference: hypotheses must be formed only for invisible

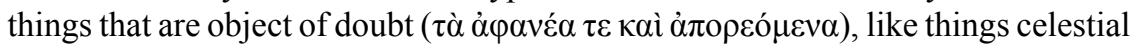
or subterranean, but one can never know if they are real or not, because there is nothing to which to refer in order to know the truth $(V M 1.3)^{28}$. On the other hand, it would be inference to define the semiotic method of medicine from its origins. The author affirms that the medical arts have a starting point and a trajectory ( $\dot{\alpha} \rho \chi \eta ்$

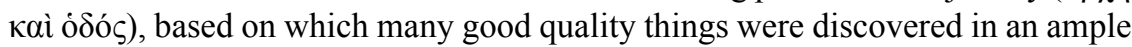

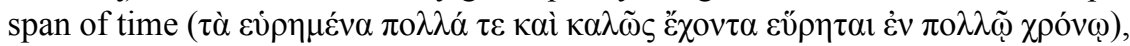
and others will also be discovered, provided that one does research using as point of departure what has already been discovered ( $V M$ 2.1). Diagnostic practice is based on this system: the doctor already knows illnesses and presents them to the patient who, listening, has only to remember what he or she has experienced ( $V M$ 2.3). The reconstruction of the past, though carried out with a certain art, is based on memory, on anamnesis.

${ }^{24}$ On semiotic or inductive method, as well as the analogy, see Manetti 1987: 64-79.

${ }^{25}$ Anaxagoras 59 B21a DK

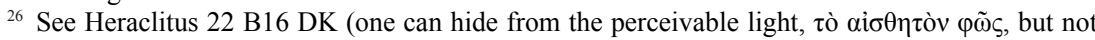

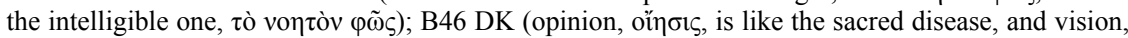
ö $\rho \alpha \_$, lies); B54 (the hidden harmony, $\dot{\alpha} \varphi \alpha v \eta ́ \varsigma$, is superior to the one that is clear, $\varphi \alpha v \varepsilon \rho \alpha ́$ ); B56

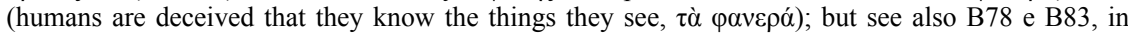
which Heraclitus emphasizes the inferiority of human knowledge compared to the divine. Mistrust of the senses comes from the Eleatics (see Parmenides 28 B7.4-5; Melissus 30 B8): Lloyd 1982: 55-56, 91-93.

${ }^{27}$ Within the work, however, this principle (though correctly posed) remains largely unfulfilled: Lloyd 1966: 438; Id. 1982: 93-94, 101-102. On the treatise's conservatism see Fantuzzi 1983.

${ }_{28}$ On this passage see Schiefsky 2005: 137-139. 
What does this art consist of? The author associates the origins of medicine to nutrition and argues that its first steps consisted in the selection of a diet adapted to survival and the treatment of the sick. In primitive times, humans fed themselves like beasts, which was the cause of many ills, as would happen today if one were

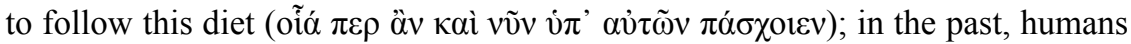
were more accustomed to it, but the weakest did suffer exactly as they would

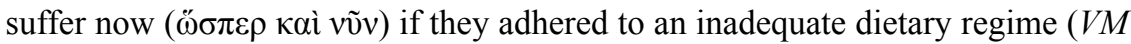
3.4). The reasoning is analogical: a present situation, empirically reconstructed, is used to illustrate a past that is no longer visible, much less verifiable. The experience gathered over time ( $\dot{\varepsilon} v \pi \circ \lambda \lambda \tilde{\omega} \chi \rho \rho \operatorname{v} \omega, V M 2.1 ; 3.3)$ comforts the doctor's "retrodiction" 29 ; that is, both retracing the course of the medical arts from their origins and dedicating himself to the diagnosis of a patient. The visible/ invisible dialectic is split into two levels. One is the spatial level, for which the exterior phenomenon, perceived with the senses, allows us to understand what is hidden in the body (cfr. VM 22.3); the other is the temporal level and consists in the fact that the trace or sign, understood in the present, allows us to access the past, that which is otherwise inaccessible -invisible- to the human eye $\mathrm{e}^{30}$.

Also in the treatise On art we find a similar formulation. The author is probably a sophist who defends the relevance of the techne specifically for the field of medicine ${ }^{31}$ and insists on the necessity of inferring diagnosis through signs when pathology is hidden and not immediately visible. The principle, of Eleatic origin, is that we can see and know only what is; while what is not can neither be seen nor known (de Arte 2.2): in a certain sense it is the possibility of knowledge that confers a real status to that which is invisible. The author repeats it often: he presumes that a cause always exists however, and rejects the presence of chance in causal sequences and in the elaborate predictions of the medical sciences $\left(6.4\right.$; cfr. 11.4) ${ }^{32}$; he argues furthermore that a sickness that is unseen can also be identified, however difficult that may be in terms of time and energy, and that which escapes the eye can also be understood with the mind's eye (11.1-2); finally, he celebrates the importance of "conjecturing" ( $\varepsilon \varepsilon \kappa \mu \alpha i \rho \varepsilon \sigma \theta \alpha i)$ through the signs $(\sigma \eta \mu \varepsilon \tilde{\alpha} \alpha)$, to render visible what is not (12.2-4). True knowledge is not something transcendent, placed in a divine realm forbidden to humans, but has descended to their level and can be deciphered thanks to human technique. This however does not imply the attenuation of the concept of truth; on the contrary, an absolute truth can be ascertained through signs. Error is considered, but depends on factors extraneous to the will and medical knowledge. Clarity on invisible

\footnotetext{
${ }^{29}$ Not coincidently, Veyne defines historical research "retrodiction" of the past; that is, the exact reverse -but in the speculative sense- of predicting the future: Veyne 1973: 251-304.

${ }^{30}$ See in particular Jori 1992.

31 This is the consensus, but contra Jouanna 1988: 179-183. On the relationship between sophistry and medicine see Hippoc., VM 20. 1; Lloyd 1982: 70-71.

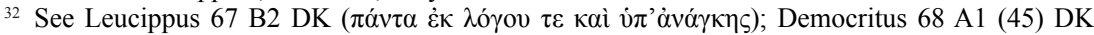

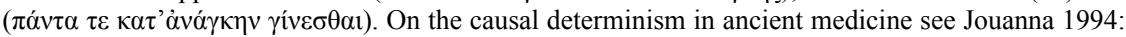
258-259.
} 
and mortal things - that Alcmaeon attributed to the gods (24 B1 DK) - is now within the reach of doctors, while the lack of clarity on their health conditions is characteristic of patients and laymen (de Arte 11.4). The past hidden in the patient's body - of which the body is itself sign- is an open book for those who possess the technique; in the same way the future can also be revealed by the physician through a correct interpretation of symptoms present, of traces that he or she are able to understand with the eyes and the mind (de Arte 7.3). To understand and to predict are no longer a privilege reserved for diviners inspired by the gods, thought it still remains the privilege of experts.

This certainty of divining imprint is clear in the beginning of the Prognostics. According to the author of the treatise, the doctor will be considered trustworthy by patients if he or she knows their situation and information about them. But this knowledge of facts derives from vision of the present, the past and the future ( $\tau$ ó

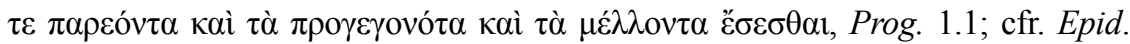
1.11), according to the formula that is, in literature, associated with the gods or prophets $^{33}$. This "divine" intelligence is manifested through an explanatory capacity that excludes what the layperson recounts, as it consists in the correct interpretation of available proof. This is believed an indicator of trustworthiness.

To sum up: medical epistemology is -or claims to be- based on empiricism, on inductive reasoning based on visible signs, in the attempt to reach by the least amount of approximation possible truths that remain hidden to the eyes of laypeople, but accessible to the vision of an expert mind. The lexicon of examination inherited by the physical philosophers who used it to define the conjectural sphere in which human knowledge was contained- becomes the expression of an inquiry adaptable to any branch of knowledge. What is invisible is no longer a mystery, not even on the temporal level ${ }^{34}$ : it is the doctor's work in fact to study the past, that is, to reconstruct the causal chain that determined the illness and predict what will happen in the future. For the doctor, in fact, knowledge acquired in the past

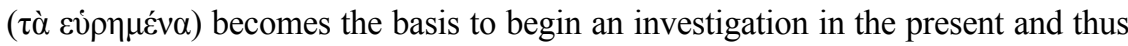
enrich future notions. The temporal dialectic follows the laws of necessity for which a phenomenon always has causes, which once individuated, can also help us to see subsequent phenomena. Time is a doctor's friend: treatments are developed over a

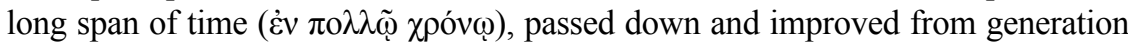
to generation. Reading treatises, there is no sense that time implicates dispersion, loss, ignorance. Doctors are masters of time; their analysis would not make sense if they could not understand what has been and what will be. It is an almost divine privilege that the patient does not have: in fact any potential errors in diagnosis and treatment depend on the patient, when he or she inappropriately refers to what has happened or delays communicating the illness to the doctor ${ }^{35}$.

\footnotetext{
33 Jouanna 2013: 84-85.

${ }^{34}$ Even the inside of the body is something inaccessible without dissection, a practice that it seems was not widespread in archaic and classic Greece: Lloyd 1982: 107-115; see Pellegrin 2007: 490-493.

${ }^{35}$ See VM 2.3; 21.1-3; Prog. 1.2-3; Flat. 1.3; de Arte 7.
} 
It can be said that the phenomenological certainty of the Hippocratics, who did not place limits on the temporal level, is in marked contrast with Augustinian ontology, which instead - precisely due to its sense of limit imposed by divine eternity- is permeated by uncertainty of knowledge of the past and the future. The mechanism with which one can look forward and backwards in time seems the same: the signs and traces left in the present, filtered by the intellect, allow us to formulate conjecture on that which has been and will be. However, contrary to Hippocrates, Augustine does not reduce discussion on time in scientific terms: for him, conjectures deriving from signs are translated into words, into a narration that reproduces and at the same time allows us to interpret the development of human events according to their temporal articulation. The mind's work of expectation and memory permits the extension of time and in time -in which it is not so much the past that enables us to infer the future, but the projection into the future that creates the past- permitting its memory. And this is what happens in artistic performances and historical narratives.

Let us come to Thucydides. In the first chapters of his work, the author explains his method and investigates the past; here there are undoubtedly similarities with the Hippocratic treatises. The lexicon of the examination is the clearest indicator ${ }^{36}$.

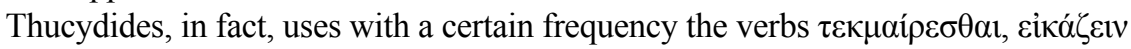

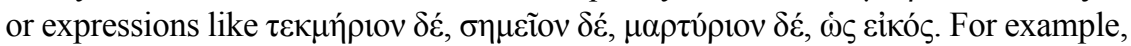

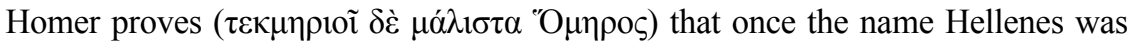

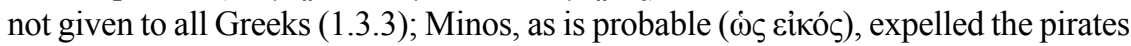
from the sea in order to collect the tributes $(1,4)$; the small towns of Greece in which arms are used show ( $\sigma \eta \mu \varepsilon \tilde{i} \sigma \delta^{\prime}$ ' $\left.\dot{\delta} \sigma \tau^{\prime}\right)$ that once it was that way for all (1.6.2); the fact that half of the ancient tombs of Delos belonged to the Carians shows ( $\mu \alpha \rho \tau$ íptov $\delta \varepsilon$ ) that they populated the majority of the islands (1.8.1); the expedition

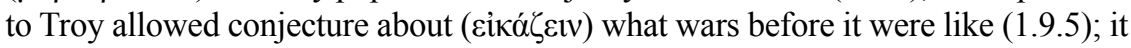
is likely (cikós) that Homer, as poet, embellished the events he described (1.10.3); as for the ships used then, it is not probable (oủ cikós) that they could hold many people, apart from the king and other nobles (1.10.4); furthermore, it is difficult to believe every piece of information ( $\pi \alpha \nu \tau i$ i $\tau \varepsilon \kappa \mu \eta \rho i ́ \omega)$ having to do with the past (1.20.1), even if those who take as starting point the evidence they put forward ( $\dot{\varepsilon} \kappa$

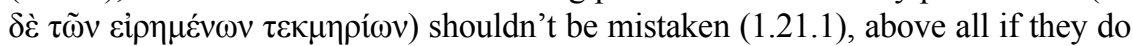
not believe the version of the poets and logographers, but that based on the most

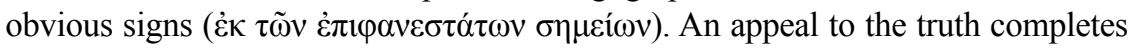
the picture: whoever reads my work, says the historian, can benefit from it, in order

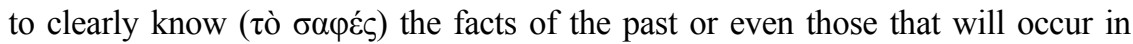
future $(1.22 .4)^{37}$.

36 See Pugliese Carratelli 1976; Hornblower 1987: 100-107, 132-133; Swain 1994; Kallet 2006: 363-367; Greenwood 2016: 91-97. Darbo-Peschanski 1989: 655-658, notes the affinities between the coeval political-legal lexicon.

37 On the historical accuracy of the Thucydidean deductions in the archaiologia, which is not 
An affinity with medical texts has been noted also in the comparison between the Greeks and barbarians in matters of piracy and dress ${ }^{38}$. Thucydides argues that the custom of bearing arms shared by some Greeks and barbarians is left over from a shared past (1.5.2-6.2); in the same way, the barbarians' current practice of doing battle clothed, especially in Asia, attests to the fact that this was the ancient custom en vogue among the Greeks, who nowadays spar nude (1.6.4-6). In both cases a present situation is projected into the past in order to establish

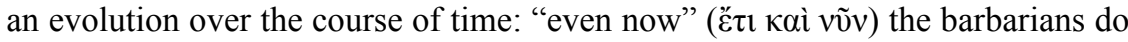
what the ancient Greeks used to do. This reasoning recalls On ancient medicine, in which the author reconstructs the effects of an animal-based diet on primitive humans on the basis of effects ascertainable in the present.

Thucydides and the Hippocratics share both a lexicon and certain analogous arguments, and this could justify the title of "scientific" historiography attributed to his work, for having a method able to guarantee not only knowledge of the past, but also prediction of the future (as we could deduce from the historian's affirmation in 1.22.4 where he defines his work as $\kappa \tau \tilde{\eta} \mu \alpha \dot{\varepsilon} \varsigma \alpha i \varepsilon i)$. This in fact is the distinctive virtue of doctors: to individuate a constant tendency across the axis of time and predict the development of the illness. For this reason, we must examine the influence of medical science on Thucydides: did his work also have a prognostic ambition of this sort? Or apart from some similarities, must we compare differences not apparent upon a first reading?

In the opening lines of his work, Thucydides declares that he began to write the history of the Peloponnesian War as soon as it erupted, foreseeing that it would have been great ( $\mu \varepsilon \dot{\gamma} \alpha \nu)$ and the most important ( $\dot{\alpha} \xi 10 \lambda \sigma \gamma \omega \dot{\tau} \alpha \tau o v)$ of all those that took place before; he infers that ( $\varepsilon \varepsilon \kappa \mu \alpha \iota \rho ́ \rho \varepsilon v о \varsigma$ ö $\tau 1 . .$.$) since Athens and Sparta$ are at the apex of their power, all the other Greeks would end up involved in the conflict, either on one side or the other. The Thucydidean prediction is therefore dependent on a completed timeline, which consists of the present, the future and the past, in that order ${ }^{39}$. The historian describes the moment in which he begins to write, just as war erupts ( $\varepsilon \dot{v} \theta \dot{v} \varsigma \kappa \alpha \theta 1 \sigma \tau \alpha \mu \varepsilon \dot{v}$ ov), then he declares what he expects for the future, and finally he expresses his judgement, which is based on the past. The present is reduced to the instant in which he realizes the importance of the war and coincides with its initial moment; the future consists of a vague expectation

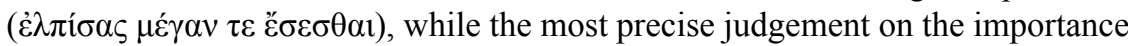
of the conflict is entrusted to a comparison with the past ( $\dot{\alpha} \xi 10 \lambda \sigma \gamma \omega \dot{\tau} \tau \tau$ ov $\tau \tilde{\omega} v$ $\pi \rho о \gamma \varepsilon \gamma \varepsilon v \eta \mu \varepsilon \dot{v} \omega v)$. It is the comparison with the past that allows him to intuit the greatness of the war that he is preparing to narrate.

\footnotetext{
in question here, see Hornblower, 1987: 92-93; see also Hornblower 1991: 7-56, for exacting commentary on these passages.

38 For a comparison between Thucydidean ethnology and that of $V M$, above mentioned, see Jouanna 1994: 243-246.

39 See Corcella 1984: 251-266.
} 
In the following paragraph Thucydides develops the idea of inquiry into the past and maintains that it is impossible to clearly reconstruct $(\sigma \alpha \varphi \tilde{\omega} \varsigma)$ the events immediately preceding the Peloponnesian War as well as those more ancient, due to the large intervening period, but that based on evidence (غ่к $\tau \varepsilon \kappa \mu \eta \rho i ́ \omega v)$, he was able to evaluate such events both in relation to the wars and other things (1.1.2). The preceding events are those of the pentecontaetia, the fifty years between the Persian wars and the outbreak of war between Sparta and Athens, to which Thucydides would dedicate considerable space in his first book (1.89$118)$; more ancient events are treated in the so-called archaiologia, immediately after the introduction of the work (1.2-19). Thucydides admits the impossibility of a certain reconstruction of all these events, but he considers a conjectural knowledge possible, thanks to which he establishes an order of magnitude.

The size comparison between the before and the after is present in all of the archaiologia: the Greeks were not more powerful in ancient times because their cities weren't large (1.2.2); before the Trojan war Greece was weak and indeed the name 'E $\lambda \lambda \alpha$ á $\zeta$ did not yet include all of the territory (1.3); the cities built afterwards were larger and richer than those constructed earlier, because they were built on the coast (1.3.7); the Trojan war was the largest expedition of those times, though inferior to the current one (1.10.3); the ships used for the expedition to Troy were smaller and could hold fewer soldiers, as they had no decks (1.10.4); the preceding eras were, for lack of wealth, weaker and they are inferior to the reputation they gained afterward thanks to the contemporary exaggerations of the poets (1.11.3); even the ships used shortly before and during the Persian wars, though more powerful than those used previously, were less powerful than the ones currently in use (1.14); the wars fought on dry land in the past were less extensive and fruitful, in victory, than those fought at sea (1.15); the Athenians' and Spartans' war preparations prior to its outbreak were greater than those when they were still allies (1.19).

In chapters 20-22, after the conclusion of the archaiologia, Thucydides again stresses the importance of the interpretation of signs in order to establish a hierarchy: people in general rely indiscriminately on oral traditions and the exaggerations of the poets and carry out research without due diligence, while the interpretation of information offered by Thucydides should be fair and demonstrate to the reader that the current war is of greater magnitude than the preceding ones ${ }^{40}$. The past is evaluated and measured against the present, or rather, the future: the former acquires meaning -that is a quantification- on the basis of the latter. It is from the zenith that Thucydides evaluates the path taken to get there, according to an evolutionary line that goes from smallest to largest.

The prefigurations of the future, spread in the archaiologia, are based precisely on this dimensional scale, which gives order or meaning to history, connecting

\footnotetext{
${ }^{40}$ On the symmetry of the argumentations in the archaiologia and on Thucydides' instrumental use of rhetoric expertise see Connor 1984: 30-31 n. 29; Tsakmakis 1995: 50-52, 62-63.
} 
and at the same time distancing the past and the present: Minos' thalassocracy (1.4) is mentioned with the Athenian one in mind; the subsequent development of the fleet, the improvements of the coastal cities and the subjugation of the poorer cities to the more powerful ones (1.7.3) are prefigurations of the Athenian maritime empire, just as the land and naval power of Agamemnon, which allowed him to lead the expedition against Troy (1.9.3-4). Even when he speaks of the ancient power of Mycenae with respect to its size, Thucydides does not hesitate to compare it to Sparta, warning that to rely on appearences can lead to error, as demonstrates the case of Athens, in appearance much more magnificent than it was in reality (1.10.1-3). In general, when the historian discusses the extent of the Trojan war and considers the Achaean attack on the basis of the unity of the deployment, the combat equipment, and the quantity of resources (1.10.5-11.3), he does so by establishing a comparison with what he knows from his own times. The staseis that take place in Greece after the heroes' return from Ilium (1.12.2) are mentioned keeping in mind the civil wars that divide the poleis after 431; the description of the Corinthian naval power (1.13.4-6) anticipates the role played by Corinth in the events leading to and surrounding the conflict against Athens.

Without knowledge of the future Thucydides would not have been able to give importance and meaning to the events of the archaiologia, nor to those that mark the beginning of the conflict or its development. The historian reads past facts in the light of knowledge and experience gained at a later time, and it is thanks to this retrospective look that he can distance the present from the past, through the opposition of big vs. little. It is significant that the furthest point of observation from the past Thucydides employs to judge history is the end of the war. In the archaiologia he mentions it three times: the first when he speaks of Aminocles, the Corinthian shipbuilder who constructed four vessels for the Samian people three hundred years before "the end of this war" (1.13.3); the second time immediately after, when he speaks of the most ancient naval battle fought between the Corinthians and the Corcyraeans about two hundred and sixty years before the same timeperiod (1.13.4); and finally when he speaks of the Spartan constitution, which goes back to a little over four hundred years "from the conclusion of this war" (1.18.1). The most famous passage in which the historian imposes this vision on the reader is the description of Pericles' death in the second book. Thucydides maintains that the war had been carried out correctly until then and that the city was united; after his death, the situation degenerated and the city was torn apart by factional struggles and governed by unscrupulous demagogues who led Athens to its defeat (2.65.5-13). This is the temporal -and therefore epistemological- framework of the Thucydidean investigation.

The historian can observe the present, as Thucydides tells us in the first lines of his work, and can take note of all that happens, but he does so in expectation of describing it in the future, once the event is over ${ }^{41}$. Danto uses the particularly

${ }^{41}$ Danto 1971: 31-40. According to Loraux 1986: 158-159, the present belongs to the historian and Araucaria. Revista Iberoamericana de Filosofía, Política y Humanidades, año 19, nº 37. Primer semestre de 2017. Pp. 213-234. ISSN 1575-6823 e-ISSN 2340-2199 doi: 10.12795/araucaria.2017.i37.11 
felicitous image of the ideal chronicler, who has the ability to give an immediate account of what occurs, and adds evidence to evidence in line with the events ${ }^{42}$. Only in this way could we postulate the existence of an entirely fixed past, but the consequence would be to empty it completely of meaning: the only thing that we can say of the past is that "it was", but it is the "no longer" that lets the events be reconstructed and narrated, renewed ${ }^{43}$. According to Danto, the historical discourse is made up of three temporal stages: the event described (the past), the event as function of the event described (the future), and the act of the narrator who writes of the events (the present) ${ }^{44}$. This last stage is described by Thucydides himself in the first chapter of his work; in it, as we have seen, the war is presented as a simple expectation and there is not yet any distance between narrator, reader and the events narrated ${ }^{45}$. The distance is established by creating an order of magnitude of the wars and other phenomena within the timeframe: in this way the facts of the past narrated in the archaiologia are judged and narrated on the basis of a future event; that is, the Peloponnesian War" ${ }^{46}$. It is the "present of the past", as Augustine says initially and then again in explaining the passing of time; it is the transfer of the future to the past that mimicks the flow of history and allows for the development of a story.

That is why the Thucydidean account is the least prognostic in nature that one can imagine. The historian simply creates false prognoses, since in narrating an event he anticipates its significance, or the meaning of its ending. This mechanism was described by Jacqueline de Romilly in a series of essays from Thucydide et l'impérialisme athénien (1947) to Histoire et raison chez Thucydide (1956), to the more recent La construction de la verité chez Thucydide (1990). Apart from the general conclusions about the Thucydidean work, with which we may or may not agree ${ }^{47}$, I would argue that De Romilly's claim is valid: Thucydides rationally constructs a truth through a narrative explanation in which he selects and orders the facts ${ }^{48}$. Let us look at some examples discussed in the most recent essay. The first concerns the imperial ambitions of Athens in Sicily ${ }^{49}$. Thucydides states twice that Athens does not get involved with the island led by ethnic motivations (Ionian Leontini's request for help in the first expedition to Sicily). This is only a

writing is history's seal, its outer limit. On Danto see Ricoeur 1983: 216-224; Grethlein 2016 (on the concept of "future past").

42 Danto 1971: 219.

${ }^{43}$ On the past as "absent de l'histoire", from which comes the need to reactualize and therefore narrate it, see Ricoeur 2000: 366-367, 471-480; Id. 2004: 40; Id. 2010: 84-89; the concept is borrowed from De Certeau 1977: 56-58, 120-121.

${ }^{44}$ Danto 1971: 220.

${ }^{45}$ Tsakmakis 1995: 30-33. On narrative fiction as recreation of past experience, see Grethlein 2010.

${ }^{46}$ Kosso 1993 does not recognize a positivist inductivism in Thucydides, but a deductive process analogous to Popper's critical rationalism.

${ }^{47}$ Montgomery 1965: 45-95, in polemics with De Romilly.

${ }^{48}$ De Romilly 1995: 32. This element is thoroughly illustrated, though perhaps with an excess of rationalism, in De Romilly 1956: 240-298.

${ }_{49}$ De Romilly 1995: 15-32. See also Laura Sancho Rocher's contribution to the present volume. 
secondary reason: it is instead motivated by a desire for conquest $(3.86 .4 ; 6.6 .1)$. Thucydides implicitly makes Alcibiades say this in his assembly speech on the opportunity for military intervention (6.18.2-3); and he makes it even clearer with the words of Hermokrates of Syracuse, to whom he attributes three different speeches meant to dismantle the argument for ethnic solidarity with the Ionian communities $(4.60 ; 61.2-3 ; 64.3 ; 6.33 .2 ; 76.2)$. The significance of the attack is expressed on the onset and is confirmed by the protagonists as the events unfold. There are also cases of short-ranging prolepsis, like Archidamus' prediction of the rage of Athens following the destruction of the Attic countryside during the first invasion (2.11.6-8): a detail that anticipates and values Pericles' ability to restrain his countrymen $(2.22 .1)^{50}$. Another prolepsis of this sort occurs when Brasidas foresees the confusion of his enemies thanks to his strategy (5.9.8), something that occurs immediately $(5.10 .7)^{51}$.

These and other correspondences are part of the skill of historical reconstruction ${ }^{52}$. The predictions are not real, but they make up the imaginary line that gives meaning to the facts ${ }^{53}$, and for this they are often expressed in the form of judgements that are very generic so as to appear universally valid. I do not however believe that this necessarily implies a philosophy of history or of some form of sociology ${ }^{54}$. Rather, it indicates a work of memory that condenses the gist of the event in a starting point, which then develops over the course of the story; just as the Augustinian metaphor of the song, in which the mind imagines all of the melody though it is up to the voice to perform the song, going over its duration to the end. The narration of the past is unraveled from the future: praesens intentio futurum in praeteritum traicit.

This leads us to attenuate (though not to exclude) the Thucydidean concept of the political utility of history and in general the idea of the "repeatability" of history, which is based on the conviction (common to medical knowledge) that it is possible to establish a constant on the axis of time ${ }^{55}$. Thucydides seems to

${ }^{50}$ De Romilly 1995: 56-57.

${ }^{51}$ De Romilly 1995: 58.

${ }^{52}$ At times, Thucydides recounts a fact in order to disprove a discourse: for example, he recounts the pentecontaetia in order to uncover the true reason behind the war (prophasis), hidden in the speeches that foreshadow Sparta's involvement (Tsakmakis 1995: 65-71; on the complex relationship between speeches and truth in Thucydidean historiography see also Tsakmakis 2017). There are also correspondences between episodes very distant from each other: the end of the Egyptian expedition $(1.104,109-110)$, recalls and foreshadows the tragic conclusion of the campaign to Sicily (7.87.6): see Hornblower 1991: 176. Rawlings 1981: 176-215, emphasizes the analogies between the III and the VIII books and between the stasis of Corcyra (427-425 BCE) and that of the Athenians (411 BCE). For other correspondences, predictions, and foreshadowing in the Thucydidean text see Morrison 2006: 265-273; Rood 2007. Finally see Golfin 2003: 15-18, for a table of the events and arguments referencing one another in the work as a whole.

${ }_{53}$ De Romilly 1995: 62.

${ }^{54}$ See Finley 1981: 16.

55 Pugliese Carratelli 1976: 471; Koselleck 1986: 114-116; Hornblower 1991: 61; Swain 1994: 317-320; Tsakmakis 1995, 55-56, 237; Moles 1999: 30-44; Id. 2001; Thomas 2006: 87; Raaflaub 2013.

Araucaria. Revista Iberoamericana de Filosofia, Política y Humanidades, año 19, n 37. Primer semestre de 2017. Pp. 213-234. ISSN 1575-6823 e-ISSN 2340-2199 doi: 10.12795/araucaria.2017.i37.11 
take us in that direction when he argues that his work will be useful for those who seek to understand facts that have occurred or will occur, which are often the same or similar on the basis of human nature $(1.22 .4)^{56}$. Yet the future he speaks about could also not be the one predicted, which depends on the past as in a medical text, and that does not mean his work necessarily possesses the pronoia he attributes to some protagonists of his history (for example, Themistocles:


subsequent age that will be narrated after him and that will be compared with his account in order to find similarities in meaning ${ }^{57}$. In this sense his work, because it is written ${ }^{58}$, survives as testimony (trace, sign) everlasting.

Thucydides is aware that he is dealing with a more difficult challenge than that of the physician. The dimension of the invisible is the temporal one and it implicates dealing with something that is no longer, though it did exist and leave traces of its journey $(1.1 .2 ; 1.22 .1)$. The process is based on speculation and does not allow for certainties: it is impossible, says Thucydides, to have an exact knowledge of the past. Time is the enemy: while doctors gain experience -and that enables them to use previous discoveries as basis for subsequent researchhistorians take note of the time that separates them from what has occurred. Judgement of previous eras (whether of wars or other things) occurs thanks to the distance from them, from the perspective that belongs to the future. The path of historians and doctors are different, though in method they are similar: each interprets traces over the course of their research, but while for doctors the past serves to understand the present and future state of the patient, for historians the past acquires meaning and can be reconstructed only on the basis of what happened after; that is, the future. Doctors conceive of time as a coherent set of constants destined to return, though each time enriched by new experiences; for historians, instead, it is a dialectic circle logically defined ${ }^{59}$, in which the time narrated is defined by the idea of limit that we found expressed in Augustine and that Ricoeur developed in the epistemological sense. For Thucydides, that outer limit is the end of the war, anticipated repeatedly over the course of his work, but -as the game of prolepses shows- the historian continuously traces temporal dividing lines beginning from which he delineates retrospectively a series of causal nexus, as is the case with the events that lead to war or facts that

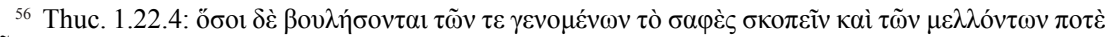

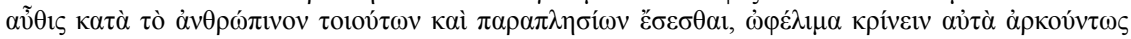

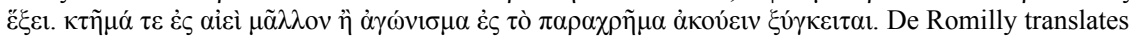
(Paris 1953): "si l'on veut voir clair dans les événements passés et dans ceux qui, à l'avenir, en vertu du caractère humain qui est le leur, présenteront des similitudes ou des analogies, qu'alors, on les juge utiles, et cela suffira: ils constituent un trésor pour toujours, plutôt qu'une production d'apparat pour un auditoire du moment".

57 Tsakmakis 2016: 103-104: ... "the ambiguous formulation allows for the understanding as both referring to events postdating the end of his (sc. of Thucydides) narrative as well as the reader's future".

${ }^{58}$ For more see Loraux 1986; Moles 2001: 207.

59 This does not mean however that Thucydides has a cyclical concept of time: Golfin 2003. 
are presented during the development of the conflict or factors that determine the defeat of Athens.

Lucian of Samosata argues that historians should see things from on high, as Homer's Zeus, moving his gaze from place to place (Luc. 59.49) ${ }^{60}$, but this is a metaphor that takes us off course. The external perspective makes sense only if transferred to a temporal dimension: it is from the "high" of their present that historians see the past down below. They can misunderstand, more or less deliberately, the signs, evidence and traces on the things examined, but their quest is however focused in that direction. It is such awareness that, I would argue, Thucydides demonstrates in the opening chapters of his work.

${ }^{60}$ On De historia conscribenda of Lucian see Tamiolaki 2016. 


\section{Bibliography}

Aurell 2011: J. Aurell, La scrittura della storia. Dai positivismi ai postmoderni (trad. it. Roma, 2011; València, 2005).

Balot, Forsdyke, Foster 2017: R. Balot, S. Forsdyke, E. Foster, The Oxford Handbook of Thucydides (Oxford, 2017).

Brunschwig 2007: J. Brunschwig, La conoscenza [in J. Brunschwig, G.E.R. Lloyd, a cura di: Il sapere greco, vol. I, ed. ital. Torino, 2007; Paris, 1996].

Cambiano 1983: G. Cambiano, Pathologie et analogie politique [in Lasserre, Mudry 1983], pp. 441-458.

Canfora 1972: L. Canfora, Totalità e selezione nella storiografia classica (Bari, 1972).

Connor 1984: W.R. Connor, Thucydides (Princeton, 1984).

Corcella 1984: A. Corcella, Erodoto e l'analogia (Palermo, 1984).

Danto 1971: A.C. Danto, Filosofia analitica della storia (trad. it. Bologna, 1971; Cambridge, 1965).

Darbo-Peschanski 1989: C. Darbo-Peschanski, La politique de l'histoire: Thucydide historien $d u$ présent, "Annales. Economies, Sociétés, Civilisations", 44 (1989), pp. 653-675.

Darbo-Peschanski 2000: C. Darbo-Peschanski, éd.: Constructions du temps dans le monde grec ancien (Paris, 2000).

Darbo-Peschanski 2000a, Temporalisations: fondements, descriptions, usages [in Darbo-Peschanski 2000], pp. 11-27.

Darbo-Peschanski 2000b, Historia et historiographie grecque: "le temps des hommes" [in Darbo-Peschanski 2000], pp. 89-114.

De Certeau 1977: M. De Certeau, La scrittura della storia (trad. it. Roma, 1977; Paris, 1975).

De Romilly 1947: J. De Romilly, Thucydide et l'impérialisme athénien. La pensée de l'historien et la genèse de l'oeuvre (Paris, 1947).

De Romilly 1956: J. De Romilly, Histoire et raison chez Thucydide (Paris, 1956).

De Romilly 1995: J. De Romilly, La costruzione della verità in Tucidide (trad. it. Firenze, 1995; Paris, 1990).

Di Benedetto 1986: V. Di Benedetto, Il medico e la malattia. La scienza di Ippocrate (Torino, 1986).

Fantuzzi 1983: M. Fantuzzi, Varianza e tenacia del polar thinking nel De prisca medicina pseudoippocratico [in Lasserre, Mudry 1983], pp. 233-247.

Fausti 2010: D. Fausti, Analogical Method, Experiment and Didacticism in the Hippocratic Treatises Generation/ Nature of the Child/ Diseases 4 [in M. Horstmanshoff, ed.: Hippocrates and Medical Education, Selected Papers presented at the XII ${ }^{\text {th }}$ International Hippocrates Colloquium, Universiteit Leiden, 24-26 August 2005, Leiden-Boston, 2010], pp. 301-321.

Finley 1981: M.I. Finley, Uso e abuso della storia (trad. it. Torino, 1981; London, 1975). 
Forsdyke 2017: S. Forsdyke, Thucydides'Historical Method [in Balot, Forsdyke, Foster 2017], pp. 19-38.

Foster, Lateiner 2012: E. Foster, D. Lateiner, eds.: Thucydides and Herodotus (Oxford, 2012).

Golfin 2003: E. Golfin, Thucydide avait-il une conception cyclique due temps?, "DHA", 29 (2003), pp. 9-29.

Greenwood 2016: E. Greenwood, Future Real and Unreal in Greek Historiography [in Lianeri 2016], pp. 79-100.

Grethlein 2010: J. Grethlein, Experientality and "Narrative Reference", with Thanks to Thucydides, "H\&T", 49 (2010), pp. 315-335.

Grethlein 2016: J. Grethlein, Ancient Historiography and 'Future Past' [in Lianeri 2016], pp. 59-77.

Grmek 1980: M.D. Grmek, éd.: Hippocratica, Actes du Colloque hippocratique de Paris, 4-9 Septembre 1978 (Paris, 1980).

Hornblower 1987: S. Hornblower, Thucydides (London, 1987).

Hornblower 1991: S. Hornblower, A Commentary on Thucydides, I: Books I-III (Oxford, 1991).

Hussey 1990: E. Hussey, The Beginnings of Epistemology: from Homer to Philolaus [in S. Everson, ed.: Epístemology, Cambridge, 1990], pp. 11-38.

Hussey 1995: E. Hussey, Ionian Inquiries. On Understanding the Presocratic Beginning of Science [in A. Powell, ed.: The Greek World, London-New York, 1995], pp. 530-549.

Jori 1992: A. Jori, Piani temporali e piani spaziali nel trattato Sull'Arte [in J.A. López Férez, coord.: Tratados hipocráticos (Estudios acerca de su contenido, forma y influencia), Actas del VIIe colloque international hippocratique, Madrid 24-29 de Septiembre de 1990, Madrid, 1992], pp. 75-90.

Jori 1996: A. Jori, Medicina e medici nell'antica Grecia. Saggio sul Perì téchnes ippocratico (Bologna, 1996).

Jouanna 1988: J. Jouanna, éd., Hippocrate, De vents, De l'art (Paris, 1988).

Jouanna 1994: J. Jouanna, Ippocrate ( trad. it. Torino, 1994; Paris, 1992).

Jouanna 2009: J. Jouanna, Hippocrate. Pour une archéologie de l'école de Cnide (Paris, 2009²).

Jouanna 2013: J. Jouanna, éd., avec la collaboration de A. Quastassion et C. Magdelaine, Hippocrate, Pronostic (Paris, 2013).

Kallet 2006: L. Kallet, Thucydides' Workshop of History and Utility Outside the Text [in Rengakos, Tsakmakis 2006], pp. 335-368.

Koselleck 1986: R. Koselleck, Futuro passato. Per una semantica dei tempi storici (trad. it. Genova, 1986; Frankfurt am Main, 1979).

Kosso 1993: P. Kosso, Historical Evidence and Epistemic Justification: Thucydides as a Case Study, "H\&T", 32 (1993), pp. 1-13.

Lasserre, Mudry 1983: F. Lasserre, Ph. Mudry, éds.: Formes de pensée dans la Collection hippocratique, Actes du IV Colloque international hippocratique, Lausanne 21-26 Septembre 1981 (Genève, 1983). 
Lianeri 2016: A. Lianeri, ed.: Knowing Future Time in and through Greek Historiography (Berlin-Boston, 2016).

Lloyd 1966: G.E.R. Lloyd, Polarity and Analogy: Two Types of Argumentation in Early Greek Thought (Cambridge, 1966).

Lloyd 1982: G.E.R. Lloyd, Magia ragione esperienza. Nascita e forme della scienza greca (trad. it. Torino, 1982; Cambridge, 1979).

Loraux 1986: N. Loraux, Thucydide a écrit la Guerre de Péloponnèse, "Mètis", 1 (1986), pp. 139-161.

Manetti 1987: G. Manetti, Le teorie del segno nell'antichità classica (Milano, 1987).

Moles 1999: J. Moles, ANA@HMA KAI KTHMA: the Inscriptional Inheritance of Ancient Historiography, "Histos", 3 (1999), pp. 27-69.

Moles 2001: J. Moles, A False Dilemma: Thucydides 'History and Historicism [in S.J. Harrison, ed.: Text, Ideas, and the Classics. Scholarship, Theory, and Classical Literature, Oxford, 2001].

Montgomery 1965: H. Montgomery, Gedanke und Tat (Lund, 1965).

Morrison 2006: J.V. Morrison, Interaction of Speech and Narrative in Thucydides [in Rengakos, Tsakmakis 2006], pp. 251-277.

Pellegrin 2007: P. Pellegrin, Medicina [in Brunschwig, Lloyd 2007], pp. 481-503 Pugliese Carratelli 1976: G.Pugliese Carratelli, Ippocrate e Tucidide [in Idem, Scritti sul mondo antico, Napoli, 1976], pp. 460-473.

Raaflaub 2013: K.A. Raaflaub, Ktēma es aiei: Thucydides' Concept of "Learning through History" and Its Realization in His Work [in Tsakmakis, Tamiolaki 2013], pp. 3-21.

Rawlings 1981: H.R. Rawlings III, The Structure of Thucydides History (Princeton, 1981).

Rengakos, Tsakmakis 2006: A. Rengakos, A. Tsakmakis, eds.: Brill's Companion to Thucydides (Leiden-Boston, 2006).

Ricoeur 1983: P. Ricoeur, Temps et récit I (Paris, 1983).

Ricoeur 1985: P. Ricoeur, Temps et récit III (Paris, 1985).

Ricoeur 2000: P. Ricoeur, La mémoire, l'histoire, l'oubli (Paris, 2000).

Ricoeur 2004: P. Ricoeur, Ricordare, dimenticare, perdonare (trad. it. Bologna, 2004; Göttingen, 1998).

Ricoeur 2010: P. Ricoeur, Filosofie critiche della storia. Ricerca, spiegazione, scrittura (trad. it Bologna, 2010; Dordrecht, 1994).

Rood 1998: T. Rood, Thucydides. Narrative and Explanation (Oxford, 1998).

Rood 2006: T. Rood, Objectivity and Authority: Thucydides' Historical Method [in Rengakos, Tsakmakis 2006], pp. 225-249.

Rood: 2007: T. Rood, Thucydides [in I.J.F. De Jong, R. Nünlist, eds.: Time in Ancient Greek Literature, Leiden-Boston, 2007], pp. 131-146.

Schiefsky 2005: M.J. Schiefsky, Hippocrates On Ancient Medicine (LondonBoston, 2005). 
Stahl 2003: H.-P. Stahl, Thucydides. Man's Place in History (engl. transl. Swansea, 2003; first German edition 1966).

Stahl 2006: H.-P. Stahl, Narrative Unity and Consistency of Thought: Composition of Event Sequences in Thucydides [in Rengakos, Tsakmakis 2006], pp. 302334.

Swain 1994: S. Swain, Man and Medicine in Thucydides, "Arethusa”, 27 (1994), pp. 303-27.

Tamiolaki 2016: M. Tamiolaki, Writing for Posterity in Ancient Historiography: Lucian's Perspective [in Lianeri 2016], pp. 293-307.

Thomas 2006: R. Thomas, Thucydides' Intellectual Milieu and the Plague [in Rengakos, Tsakmakis 2006], pp. 87-108.

Thomas 2017: R. Thomas, Thucydides and his Intellectual Milieu [in Balot, Forsdyke, Foster 2017], pp. 567-586.

Tsakmakis 1995: A. Tsakmakis, Thukydides über die Vergangenheit (Tübingen, 1995).

Tsakmakis 2016: A. Tsakmakis, Between Thucydides and the Future: Narrative Prolepsis and Xenophon's Concept of Historiography [in Lianeri 2016], pp. 102-117.

Tsakmakis 2017: A. Tsakmakis, Speeches [in Balot, Forsdyke, Foster 2017], pp. 267-281.

Tsakmakis, Tamiolaki 2013: A. Tsakmakis, M. Tamiolaki, eds.: Thucydides between History and Literature (Berlin-Boston, 2013).

Vegetti 1983: M. Vegetti, Metafora politica e immagine del corpo negli scritti ippocratici [in Lasserre, Mudry 1983], pp. 459-469.

Veyne 1973: P. Veyne, Come si scrive la storia. Saggio di epistemologia ( trad. it. Roma-Bari, 1973; Paris, 1971). 